\title{
Učinkovitost javne uprave u Hrvatskoj $u$ postupcima odabira projekata sufinanciranih putem fondova Europske unije
}

Jakša Puljiz*

Sanja Malekovićn

Sanja Tišma $a^{* * *}$

\author{
https://doi.org/ 10.31297/hkju.21.2.5 \\ UDK $\quad 338.246 .027(4) E U$ \\ 339.923:061.1>(497.5:4EU) \\ Review scientific paper / pregledni znanstveni rad \\ Received / primljeno: 26.10.2020. \\ Accepted / prihvaćeno: 07. 05. 2021.
}

Kvalitetan proces odabira projekata za financiranje jedan je od ključnih elemenata koji određuju uspjeh kohezijske politike. Razvoj i primjena kriterija odabira projekata u

* Dr. sc. Jakša Puljiz, Institut za razvoj i međunarodne odnose, Zagreb, Hrvatska, znanstveni suradnik (research associate, Institute for Development and International Relations, Zagreb, Croatia, e-mail: jpuljiz@irmo.hr).

ORCID https://orcid.org/0000-0002-1690-2346

** Dr. sc. Sanja Maleković, Institut za razvoj i međunarodne odnose, Zagreb, Hrvatska, znanstvena savjetnica (scientific advisor, Institute for Development and International Relations, Zagreb, Croatia, e-mail: msanja@irmo.hr).

ORCID https://orcid.org/0000-0003-2943-3689

*** Dr. sc. Sanja Tišma, Institut za razvoj i međunarodne odnose, Zagreb, Hrvatska (scientific advisor, Institute for Development and International Relations, Zagreb, Croatia, e-mail: sanja.tisma@irmo.hr).

ORCID https://orcid.org/0000-0002-6407-2842 
nadležnosti su pojedinih zemalja članica Europske unije (EU), ali uz obvezu poštivanja ključnih načela utvrđenih propisima EU-a. Cilj je rada ocijeniti kvalitetu sustava odabira projekata u okviru provedbe Operativnog programa konkurentnost i kohezija 2014. - 2020. (OPKK) kao financijski najvažnijeg programa sufinanciranog iz proračuna EU-a u Hrvatskoj u proračunskom razdoblju 2014. - 2020. Rezultati istraživanja pokazuju da je sustav odabira projekata vrlo složen te zahtijeva vrlo visok angažman uključenih sudionika. Po tome se Hrvatska svrstava u skupinu novih zemalja članica EU-a koje obilježava visok stupanj standardiziranosti procesa s prilično kompleksnim postupcima odabira. Uz određene pozitivne učinke u vezi s odabirom relevantnih projekata, posljedica je takva pristupa vrlo sporo donošenje odluka o odabiru projekata, što je doprinijelo slabijem povlačenju raspoloživih sredstava EU-a.

Ključne riječi: kohezijska politika, Hrvatska, učinkovitost javne uprave, vrednovanje, odabir projekata

\section{Uvod}

Kohezijska politika EU-a ima iznimno značenje za razvoj Republike $\mathrm{Hr}-$ vatske. To se, prije svega, ogleda u znatnim financijskim koristima, odnosno dodatnim mogućnostima financiranja razvojnih projekata uz pomoć sredstava EU-a namijenjenih poticanju razvoja slabije razvijenih država i regija. Osim izravnih financijskih i socioekonomskih učinaka, kohezijska politika donosi niz drugih, važnih koristi, ponajviše u vidu prijenosa znanja o pojedinim praksama kojima se (potencijalno) poboljšavaju nacionalne javne politike. U većini slučajeva riječ je o primjeni različitih metodologija i postupaka kojima je cilj poboljšati upravljanje sredstvima kohezijske politike. Dobar je primjer uvođenja novih metodologija obvezna provedba postupka neovisnog vrednovanja izrade i provedbe planskih dokumenata kohezijske politike kako bi se pratila i podignula njezina kvaliteta i osigurali što veći pozitivni učinci ulaganja u pojedinoj zemlji članici te Europskoj uniji u cjelini. Kohezijska politika postala je glavni pokretač za širenje prakse vrednovanja u EU-u, a posebno u južnim i novim zemljama članicama koje nisu imale vlastitu tradiciju vrednovanja javnih politika (European Commission, 2013). Najveća važnost vrednovanja u 
kontekstu kohezijske politike proizlazi iz njegove glavne svrhe, poboljšanja kvalitete izrade i provedbe razvojnih programa, što ga čini važnim alatom u kontekstu vođenja javnih politika (Maleković et al., 2019). Važna korist vrednovanja odnosi se na institucijsko osnaživanje s obzirom na to da se poboljšavaju i jačaju sposobnosti sudionika programa u planiranju i provedbi programa (European Commission, 2013). Osim toga, ističe se i važnost jačeg osjećaja vlasništva i odgovornosti ključnih dionika za sam program (Batterbury, 2006).

S druge strane, provedba kohezijske politike sa sobom donosi i neke manje poželjne učinke poput povećanja administrativne kompleksnosti za dionike u procesu korištenja fondovima kohezijske politike. Stoga ne iznenađuje često isticanje potrebe postizanja odgovarajuće ravnoteže između financijske/proceduralne odgovornosti i odgovornosti za rezultate i učinke, s obzirom na to da su aktivnosti nadležnih administrativnih tijela i dalje pretjerano usmjerene na pitanja financijske i proceduralne odgovornosti, a premalo na ostvarivanje planiranih rezultata i učinaka (Polverari, 2011). Svjesna problema prevelike složenosti kohezijske politike Europska komisija (EK) donijela je 2018. čak 80 mjera za pojednostavnjivanje provedbe politike u financijskoj perspektivi 2021. - 2027. (European Commission, 2018). Vrlo složen pravni okvir za provedbu kohezijske politike dodatno je uvećan procesom tzv. pozlaćivanja (engl. gold-plating), koji se odnosi na prakse zemalja članica da osim zahtjeva, obveza ili standarda koji proizlaze iz samog zakonodavstva EU-a utvrde dodatne zahtjeve, obveze ili standarde koji nadilaze ono što propisuje zakonodavstvo EU-a (Tsipouri, 2014; European Commission, 2016). Hrvatska se nalazi među zemljama čije je upravljanje kohezijskom politikom u znatnoj mjeri opterećeno pitanjima financijske i proceduralne odgovornosti sudionika provedbe na svim razinama upravljanja (Puljiz, Maleković \& Keser, 2018). To je posebno otežavajuća okolnost za jedinice lokalne samouprave suočene sa slabijim apsorpcijskim kapacitetima, a koje se teško nose s problemom pretjerane regulacije (Đulabić, 2017).

Predmet je ovog rada vrednovanje funkcioniranja jednoga specifičnog segmenta procesa upravljanja kohezijskom politikom u Hrvatskoj, a to je proces odabira projektnih prijedloga. ${ }^{1}$ Riječ je o području koje je do sada vrlo slabo istraženo premda proces odabira projekata ima veliku važnost za sve javne politike koje se bave financiranjem različitih oblika ulaga-

${ }^{1}$ Rad se jednim dijelom oslanja na rezultate prethodnog vrednovanja sustava odabira projekata u okviru Operativnog programa Konkurentnost i kohezija koje su proveli Ecorys i IRMO (2019). 
nja. Osnovni smisao primjene postupka odabira jest osigurati da sredstva budu uložena u one projekte koji donose najveću korist u ostvarivanju ključnih ciljeva politika (Meredith \& Mantel, 2009). U tom kontekstu nužno je osigurati primjenu istog pristupa kod ocjenjivanja da bi se izbjeglo neravnopravno natjecanje između različitih projekata. Stoga je potrebno uspostaviti zajednički sustav mjerenja i tako omogućiti izravnu usporedbu alternativa za financiranje (Dutra, Ribero \& Carvalho, 2014). Odabir projekata u tom je smislu od ključne važnosti za uspješnu provedbu i ostvarenje ciljeva organizacije (Jigeesh, 2012).

Provedba kohezijske politike temelji se na provedbi programa koji se u terminologiji kohezijske politike nazivaju operativnim programima. Njihovom se provedbom žele ostvariti specifični nacionalni odnosno regionalni ciljevi zemlje članice te doprinijeti ostvarenju ključnih razvojnih ciljeva EU-a. Temeljni su instrumenti postizanja tih ciljeva pojedinačni projekti, odnosno stotine i tisuće projekata koji se financiraju u okviru pojedinog programa. Nositelji projekata brojni su akteri, od jedinica lokalne i regionalne samouprave do poduzetnika, organizacija civilnog društva te središnjih državnih tijela i drugih. U tom smislu, osiguranje učinkovita, djelotvorna i transparentna procesa odabira projekata jedan je od važnih uvjeta dobra funkcioniranja kohezijske politike i postizanja utvrđenih razvojnih ciljeva. Ujedno je to i najbolji način izbjegavanja stvaranja negativne slike o samoj kohezijskoj politici kao mehanizmu usmjeravanja financijskih sredstava za projekte upitne kvalitete i upitna doprinosa ciljevima EU-a.

Rad je usmjeren na vrednovanje sustava odabira projekata u okviru Operativnog programa Konkurentnost i kohezija 2014. - 2020. (OPKK). Riječ je o dokumentu kojim se utvrđuju prioriteti korištenja 6,8 milijardi eura iz Europskog fonda za regionalni razvoj i Kohezijskog fonda u Republici $\mathrm{Hr}$ vatskoj za financijsko razdoblje 2014. - 2020. ${ }^{2}$ Programom se osiguravaju znatna ulaganja u infrastrukturne i druge projekte u područjima okoliša, prometa, poduzetništva, istraživanja i razvoja, energetike, informacijskokomunikacijske tehnologije (IKT), obrazovanja i drugih.

Rad je organiziran na sljedeći način: nakon uvoda slijedi pregled relevantne literature u drugom poglavlju, dok se u trećem poglavlju detaljnije pojašnjavaju ključna načela u skladu s kojima funkcionira proces odabira

${ }^{2}$ Premda se financijsko razdoblje odnosi na spomenuto sedmogodišnje razdoblje, stvarna provedba traje do kraja 2023. godine. Riječ je o tzv. N+3 pravilu na temelju kojeg se sredstva dodijeljena u n-toj godini mogu trošiti iduće tri godine. Stoga se sredstva dodijeljena u 2020. godini mogu trošiti sve do kraja 2023. godine. 
projekata u kontekstu kohezijske politike. To poglavlje sadržava pregled relevantnih pravnih odredbi te ključnih obilježja glavnih postupaka odabira. Četvrto poglavlje donosi opis metodologija i ključnih empirijskih nalaza analize sustava odabira projekata - njegove administrativne učinkovitosti te sposobnosti da vodi k izboru projekata koji osiguravaju najveći doprinos ključnim ciljevima OPKK-a. U zadnjem poglavlju izneseni su zaključci.

\section{Pregled literature}

Sustav odabira projekata kakav danas poznajemo rezultat je dugogodišnjeg razvoja koji traje više od dva desetljeća. Naime, sustav odabira projekata počeo se snažnije razvijati od druge polovice 90 -ih godina prošlog stoljeća, nakon prethodno provedenih reformi kohezijske politike kojima je uveden nov pristup planiranju, provedbi i praćenju rezultata same politike. ${ }^{3}$ Do provedbe reforme odabir projekata financiranih strukturnim fondovima EU-a bio je prepušten vladama zemalja članica te se na sredstva fondova gledalo kao na svojevrsnu kompenzaciju za uplate država članica u zajednički proračun EU-a (Sutcliffe, 2000). Bachtler i Taylor (1999) mišljenja su da je odabir projekata u prvoj financijskoj perspektivi moderne kohezijske politike koja je trajala od 1989. do 1993. bio na rudimentarnoj razini te je razvoj sustavnijeg pristupa odabiru projekata započeo tek tijekom financijske perspektive 1994. - 2000. Autori naglašavaju da je pristup postupno evoluirao od „utvrđivanja liste projekata“ prema mnogo složenijim metodama odabira projekata s vrlo velikim naglaskom na poboljšanju procesa vrednovanja projekata koji sve više postaje proaktivan i strateški. Ferry i dr. (2007) ističu da je razvoj sustava odabira projekata u posljednjih 15-ak godina bio jedan od ključnih elemenata poboljšanja upravljanja (operativnim) programima. Međutim, sve zahtjevnije procedure za prijavu i odabir projekata istodobno su dovele do određenih negativnih efekata poput smanjene zainteresiranosti (jednog dijela) potencijalnih prijavitelja za sudjelovanje na natječajima. Tako Wostner (2008) ističe da su pretjerana birokratiziranost i složenost procesa prijavljivanja i odabira projekata dovele do iznadproporcionalno velikih troškova prijavljivanja, što je među prijaviteljima utjecalo na stvaranje negativne percepcije isplativosti prijavljivanja. Svjesnost o problemu prevelika administrativnog optereće-

${ }^{3}$ Više detalja o reformama kohezijske politike i utjecaju na odabir projekata u Manzella \& Mendez, 2009. 
nja postupaka odabira projekata utjecala je na pokušaj nadležnih tijela da smanje kompleksnost postupaka. Bachtler i dr. (2014) navode da se s vremenom smanjilo administrativno opterećenje u procesu prijave i odabira projekata, čemu su posebno pomogle intenzivnije konzultacije nadležnih tijela s potencijalnim prijaviteljima. Osim pitanja administrativnog opterećenja, sve veća pozornost pridaje se ocjeni povezanosti postupaka odabira projekata i ostvarenih rezultata. Europski revizorski sud (European Court of Auditors, 2018) proveo je posebno istraživanje o načinu odabira i praćenja rezultata projekata financiranih Europskim fondom za regionalni razvoj i Europskim socijalnim fondom. U svojim nalazima sud ističe da je proces odabira projekata i dalje nedovoljno usmjeren na učinke koje bi projekti trebali ostvariti te naglašava potrebu da tijela zadužena za upravljanje operativnim programima primjenjuju kriterije odabira koji daju jasnu prednost projektima koji najviše doprinose ciljevima programa te imaju najveću vjerojatnost ostvarivanja planiranih rezultata. Preporučuje se da bi kriteriji za odabir projekata trebali uključiti ne samo kvantificirane pokazatelje očekivanih neposrednih rezultata provedbe projekta (npr. broj odrađenih treninga) već i kvantificirane pokazatelje očekivanih ishoda (kratkoročnih učinaka) ostvarenih na temelju provedbe projekata (npr. povećanje zaposlenosti nakon provedenih treninga). Također, sud ističe da bi se za sve javne pozive trebao osigurati dovoljan broj prijavitelja te da bi bilo važno odluke o odabiru donositi na temelju međusobne usporedbe projektnih prijava, a ne prema vremenu zaprimanja uz zadovoljenje minimalnog standarda kvalitete prijave. Vezano za tu preporuku, zanimljiv je odgovor EK-a Europskomu revizorskom sudu, prema kojem EK smatra da je kod mnogih oblika davanja potpora mnogo učinkovitije postaviti minimalne standarde kvalitete prijave nego provoditi ocjenjivanje $\mathrm{i}$ međusobnu usporedbu svih zaprimljenih prijava jer, prema viđenju EK-a, potonja metoda ne dovodi nužno do bolje ukupne kvalitete projekata, a istodobno je prati nepotreban dodatni administrativni teret.

Vrednovanje koje je proveo Rambùll (2012) također pokazuje da je, s aspekta što boljeg doprinosa ostvarenju ciljeva programa, poželjno provoditi pozive s međusobnom usporedbom prijavljenih projekata. U spomenutom istraživanju vrednovani su pozivi trajnog karaktera (stalno otvoreni) i pozivi privremenog karaktera (vremenski ograničeni). Pokazalo se da obje vrste poziva imaju važne prednosti. Primjerice, privremeni pozivi potiču natjecanje među prijaviteljima, selektivniji su u odabiru, omogućuju izravan odgovor na promijenjene potrebe tijekom financijske perspektive te omogućuju bolji proces učenja između poziva. S druge strane, trajno otvoreni pozivi, procjenjuje se, pružaju veću fleksibilnost prijaviteljima, 
koji imaju dovoljno vremena za kvalitetnu pripremu prijava, smanjuju administrativni teret vezano za pripremu i otvaranje natječaja te imaju manji broj odbačenih prijava, što pak smanjuje razinu uzaludno uloženih resursa u pripremu projekata. Istraživanje je također pokazalo zanimljive razlike u pristupu procesu odabira među zemljama članicama. Pokazalo se da nove zemlje članice, za razliku od starih, imaju znatno zahtjevniji postupak odabira, prije svega što se tiče količine dokumentacije koja se traži od podnositelja prijave. Također, postupci odabira projekata u novim zemljama članicama uglavnom se temelje na bodovnim ljestvicama, dok se kod starih zemalja članica u većoj mjeri preferira kvalitativna ocjena pojedinog projekta. Na primjeru dviju poljskih regija Dabrowski (2012) zaključuje da je proces odlučivanja o projektima financiranim fondovima kohezijske politike u prvim godinama članstva Poljske u EU-u bio prilično neefikasan i praćen različitim političkim utjecajima. Međutim, s vremenom je proces evoluirao i znatno se poboljšao, posebno što se tiče racionalizacije i standardizacije procedura odabira projekata. Idczak i Musiałkowska (2014) analiziraju sustav odabira projekata EU-a u Poljskoj 2007. - 2013. te zaključuju da je sustav prilično kvalitetan. Posebno naglašavaju da je element natjecanja među prijaviteljima znatno doprinio ukupnoj kvaliteti odabira projekata. Osim toga, ističu važnost odabira iskusnih ocjenjivača projektnih prijedloga kao i održavanja pripremnih sastanaka s ocjenjivačima prije početka samog vrednovanja. Međutim, pritom ističu i potrebu za većom transparentnošću odabira vanjskih ocjenjivača. U slučaju investicijskih projekata znatne financijske vrijednosti odluka o odabiru projekata u nadležnosti je EK-a, pri čemu je postupak odabira individualan za svaki projektni prijedlog te uključuje obveznu izradu analize troškova i koristi koja predstavlja metodologiju s dugom tradicijom primjene kada su u pitanju javne investicije (Florio et al., 2018). ${ }^{4}$ Primjeri takvih projekata najčešće se mogu naći u sektorima prometa i zaštite okoliša. Pristup odabiru prijedloga projekata za financiranje znatno je napredovao i u drugim područjima koja su predmet financiranja iz proračuna EU-a. Tako je npr. istraživanje metodologije odabira projekata financiranih programom „EU za zdravlje" koji se također financira putem proračuna EU-a pokazalo da se s vremenom pristup selekciji projekata unaprijedio, posebno u smislu

${ }^{4}$ Npr. u proračunskom razdoblju 2014. - 2020. svi projekti čiji ukupni prihvatlijivi troškovi premašuju 50 milijuna eura, odnosno 75 milijuna eura u sektorima prometa i zaštite okoliša, prolaze evaluaciju nadležnih službi EK-a i posebnog tijela za potporu projektima JASPERS (Joint assistance to support project in European regions) te projekti obvezno moraju imati pozitivan nalaz analize troškova i koristi. Takvi se projekti prema regulativi EU-a nazivaju velikim projektima (major projects). 
standardizacije postupka bodovanja te interne konzistentnosti ključnih kriterija, čime je proces odlučivanja o financiranim projektima znatno poboljšan (Van den Broucke, Dargent \& Pletschette, 2011).

\section{Kohezijska politika, Operativni program Konkurentnost i kohezija 2014. - 2020. i postupak odabira projekata}

Osnovne smjernice za provedbu postupka odabira projekata objavljene su u pravnim aktima EU-a koji uređuju pitanje korištenja fondovima kohezijske politike. Za financijsko razdoblje 2014. - 2020. to je Uredba (EU) br. 1303/2013 Europskog parlamenta i Vijeća kao krovna uredba koja uređuje pitanje korištenja fondovima kohezijske politike kao i drugim fondovima koji zajedno čine tzv. Europske strukturne i investicijske fondove. Prema čl. 125. spomenute uredbe, tijelo nadležno za upravljanje programom (upravljačko tijelo) utvrđuje odgovarajuće postupke odabira projekata i kriterije koji: i. osiguravaju doprinos projekata ostvarivanju specifičnih ciljeva i rezultata odgovarajućih prioriteta; ii. nediskriminirajući su i transparentni, iii. uzimaju u obzir opća načela navedena u člancima 7. i 8. ${ }^{5}$

Odobrenje metodologije i kriterija koji će se koristiti pri odabiru projekata daje Odbor za praćenje koji predstavlja radno tijelo nadležno za praćenje uspješnosti provedbe operativnog programa. Članovi su tog tijela predstavnici svih ključnih dionika na koje se odnosi provedba programa kao i predstavnici nositelja samih projekata poput predstavnika jedinica lokalne i regionalne samouprave, akademske zajednice, poduzetnika, civilnog društva i drugih dionika.

Nadležnost za provedbu postupka odabira projekata ima upravljačko tijelo. Pritom upravljačko tijelo može delegirati ovlasti za provedbu postupka odabira projekata na neko drugo ovlašteno tijelo (tzv. posredničko tijelo), a koje obično predstavlja ministarstvo nadležno za tematsko područje na koje se postupak odabira odnosi (poduzetništvo, promet, obrazovanje itd.). Europska komisija nije izravno uključena u odabir projekata osim u slučaju tzv. velikih projekata, ali posredno ipak ostvaruje određen utjecaj procesima programiranja, odnosno izrade operativnih programa. Naime,

5 Riječ je o načelima kojima se osiguravaju promicanje ravnopravnosti žena i muškaraca i zabrana diskriminacije te o načelima održivog razvoja. 
operativni programi već sadržavaju određene važne napomene o kriterijima odabira projekata (2014. - 2020. to su bila tzv. vodeća načela za odabir operacija). Osim toga, EK ima savjetničku ulogu u odborima za praćenje operativnih programa na kojima se prihvaćaju metodologija i kriteriji za odabir projekata te daju savjeti o najboljoj praksi koja se primjenjuje u zemljama članicama.

U praksi se primjenjuju različiti postupci odabira projekata. Tako npr. postoje različite vrste poziva koje nadležna tijela raspisuju za prikupljanje i odabir projektnih prijedloga, ovisno o njihovu trajanju i otvorenosti. Tablica 1. prikazuje različita obilježja postupka odabira.

Tablica 1. Ključna obilježja različitib vrsta postupka odabira

\begin{tabular}{|c|c|c|c|}
\hline $\begin{array}{c}\text { Trajanje poziva za } \\
\text { dostavu projektnih } \\
\text { prijedloga }\end{array}$ & $\begin{array}{c}\text { Otvorenost } \\
\text { poziva za dostavu } \\
\text { projektnih } \\
\text { prijedloga }\end{array}$ & $\begin{array}{l}\text { Metoda odabira } \\
\text { projektnih } \\
\text { prijedloga }\end{array}$ & $\begin{array}{l}\text { Kriteriji odabira } \\
\text { projektnih } \\
\text { prijedloga }\end{array}$ \\
\hline neograničen & otvoren & $\begin{array}{l}\text { međusobna } \\
\text { usporedba svih } \\
\text { zaprimljenih } \\
\text { projekata }\end{array}$ & da/ne kriteriji \\
\hline ograničen/privremen & $\begin{array}{l}\text { ograničen - bez } \\
\text { unaprijed definirana } \\
\text { odabira }\end{array}$ & $\begin{array}{l}\text { prema redoslijedu } \\
\text { zaprimanja / } \\
\text { automatski }\end{array}$ & $\begin{array}{l}\text { bodovno rangiranje } \\
\text { s minimalnim } \\
\text { bodovnim pragom }\end{array}$ \\
\hline \multirow[t]{2}{*}{$\begin{array}{l}\text { mješovit (ograničen, } \\
\text { ali s dodatnim } \\
\text { rokovima) }\end{array}$} & $\begin{array}{l}\text { ograničen - } \\
\text { predefiniran odabir }\end{array}$ & & $\begin{array}{l}\text { bodovno rangiranje } \\
\text { bez minimalnog } \\
\text { praga }\end{array}$ \\
\hline & & & kvalitativna ocjena \\
\hline
\end{tabular}

Izvor: Obrada autora na temelju podataka iz Rambùll (2012); Wostner (2008); Ferry et al. (2007).

Postupci odabira projekata mogu kombinirati različita obilježja. Tako je, primjerice, moguće imati poziv koji će biti privremeno otvoren, i to samo za neke potencijalne prijavitelje (npr. samo za određen broj jedinica lokalne samouprave), pri čemu će se projektni prijedlozi ocjenjivati međusobnom usporedbom svih zaprimljenih kriterija, a rangiranje će se temeljiti na bodovima bez primjene minimalnoga bodovnog praga. Koja će se kombinacija obilježja primijeniti u pojedinom postupku odabira, ovisi o odluci upravljačkog tijela odnosno posredničkog tijela, ako je ono odgovorno za provedbu postupka odabira, s tim da se u potonjem slučaju upravljačko 
tijelo mora suglasiti s prijedlogom. Odluka o primjeni određenog postupka odabira uvjetovana je nizom faktora od kojih su posebno važni: a) veličina projekta - za manje projekte često se primjenjuju pojednostavnjene procedure odabira, dok se za veće projekte koriste složeniji postupci; b) vrsta projekta - ovisno o tome je li riječ o infrastrukturnom projektu (npr. u području okoliša), potpori za poduzetnike, ulaganju u obrazovanje radne snage itd.; c) strateška važnost projekta - je li riječ o projektima od posebnoga nacionalnog interesa ili projektima od lokalne ili regionalne važnosti. Naravno, moguće je primijeniti i neke druge faktore, prije svega one koji su od specifične važnosti za neko tematsko područje.

U slučaju OPKK-a, dodjela bespovratnih sredstava temelji se na pozivima za dodjelu sredstava koje objavljuju nadležna državna tijela i u kojima su razrađeni kriteriji odabira projektnih prijedloga koji se podnose na pojedini poziv, odnosno postupak za dodjelu bespovratnih sredstava. Početna osnova za razradu kriterija za odabir projekata jest sam tekst OPKK-a u kojem se navode načela za odabir, ciljane skupine i potencijalni prijavitelji kao i primjeri mogućih aktivnosti koje bi bile predmet financiranja. Daljnja razrada različitih postupaka odabira u pojedinim područjima operativnog programa provodi se na temelju tzv. Zajedničkih nacionalnih pravila (ZNP). Riječ je o dokumentu koji sadržava specifična pravila postupanja državnih tijela odgovornih za provedbu operativnih programa, uključujući i postupak odabira projektnih prijedloga. Prvi je korak u razradi postupka izrada tzv. programskog dodatka od nadležnoga državnog tijela. Taj dokument sadržava detaljnije podatke o planiranom pozivu na dostavu projektnih prijedloga, uključujući podatke o aktivnostima koje se planiraju poduprijeti, financiranju poziva, prihvatljivim troškovima, prijaviteljima i partnerima, pokazateljima za praćenje provedbe te ostale podatke koje nadležno tijelo smatra bitnim. Nakon izrade i prihvaćanja programskog dodatka, slijedi razrada kriterija odabira projekata za pojedini postupak dodjele bespovratnih sredstava. Prema odredbama ZNP-ova, u postupku odabira primjenjuju se dvije osnovne vrste kriterija (MRRFEU, 2018):

- kriteriji pribvatliivosti - osnovni kriteriji koji svi moraju biti ispunjeni da bi se projektni prijedlog mogao uzeti u obzir za financiranje. Najčešće se njima ocjenjuje prihvatljivost prijavitelja, prihvatljivost partnera (ako ih ima), prihvatljivost projektnih aktivnosti te troškova projekta s obzirom na ciljeve i pravila poziva. Kriteriji prihvatljivosti procjenjuju se u obliku DA/NE kriterija

- kriteriji odabira - kriteriji na temelju kojih se ocjenjuje kvaliteta projektnih prijedloga ako su prethodno zadovoljili kriterije prihvatljivosti. 
U pravilu se primjenjuju u obliku bodovne ljestvice, pri čemu je 100 bodova najčešće utvrđeno kao maksimum.

Prema ZNP-ovima, kod kriterija odabira primjenjuje se sedam obveznih glavnih kriterija odabira koji se potom uvrštavaju u tekst dokumentacije pojedinog postupka dodjele (unutar uputa za prijavitelje) te dodatno razrađuju u posebnim pitanjima i potpitanjima:

- vrijednost za novac

- dizajn i zrelost projekta

- financijska održivost projekta

- provedbeni kapaciteti prijavitelja

- promicanje jednakih mogućnosti i socijalne uključenosti

- promicanje održivog razvoja

- doprinos projektnog prijedloga rješavanju specifičnih razvojnih problema na određenom teritoriju.

Također postoji mogućnost primjene dodatnih kriterija ovisno o ciljevima pojedinog poziva:

- povezanost s drugim projektima relevantnim za predmetni sektor

- opseg i snaga partnerstva

- inovativnost projekta.

Detaljna razrada kriterija odabira projektnih prijedloga nalazi se u uputama za prijavitelje u sklopu natječajne dokumentacije svakoga pojedinog poziva. Nakon razrade kriterija odabira, pristupa se osnivanju Odbora za odabir projekata, radnog tijela čiji su članovi predstavnici nadležnih državnih tijela, ovisno o području financiranja. Odbor za odabir ocjenjuje kvalitetu projekata, a može provoditi i ocjenu prihvatljivosti projekata ako se za to ne odredi neko drugo tijelo ${ }^{6}$ te šalje prijedlog za sklapanje ugovora o dodjeli bespovratnih sredstava čelniku nadležnoga državnog tijela (ili više njih).

ZNP-ovi propisuju četiri vrste postupaka dodjele bespovratnih sredstava (MRRFEU, 2018):

1) Otvoreni postupak - otvoreni poziv na dostavu projektnih prijedloga kojem je cilj privući što veći broj potencijalnih prijavitelja. Otvoreni poziv omogućava dva načina natjecanja podnesenih projektnih prijedloga:

${ }^{6}$ U praksi prihvatljivost projekata u slučaju OPKK-a obično provodi Središnja agencija za financiranje i ugovaranje (SAFU). 
- modalitet privremenog poziva, gdje se nakon završetka roka zaprimanja prijava provodi ocjenjivanje svih zaprimljenih prijava, njihovo rangiranje i konačan odabir s obzirom na ostvareni rang i dostupna bespovratna sredstva

- ili se radi po načelu prednosti prema datumu i vremenu podnošenja pojedinoga projektnog prijedloga gdje se provjera prijedloga ocjenjuje prema redoslijedu zaprimanja te se odabiru prijave koje zadovoljavaju pozivom utvrđen bodovni minimum, bez međusobne usporedbe projektnih prijedloga.

2) Ograničeni postupak - vrsta postupka dodjele bespovratnih sredstava namijenjenih unaprijed određenim prijaviteljima. Ovisno o raspoloživoj financijskoj omotnici i broju prijavitelja koji sudjeluju u postupku ograničenog poziva moguće je: a) natjecanje unaprijed određena broja prijavitelja; b) pregovaranje s jednim ili više prijavitelja i c) natjecanje ograničena broja podnesenih projektnih prijedloga po kriteriju prednosti prema vremenu podnošenja pojedinoga projektnog prijedloga.

3) Izravna dodjela - dodjela bespovratnih sredstava unaprijed utvrdenom prijavitelju, a odnosi se na: a) strateške projekte za čiju provedbu postoji samo jedan unaprijed određen prijavitelj, b) projekte koji se nastavljaju iz prethodne financijske perspektive te c) projekte financirane iz prioritetne osi tehničke pomoći za dodjelu sredstava tijelima koja su u operativnom programu navedena kao korisnici sredstava tehničke pomoći.

4) Odabir velikih projekata - postupak izravne dodjele operacija/projekata čiji ukupni prihvatljivi troškovi premašuju 50 milijuna eura, osim u sektoru prometa gdje iznos troškova premašuje 75 milijuna eura.

Odluka o odabiru pojedine vrste postupka ovisi o nizu faktora kao što su tehnička priroda projekata, raspoloživa financijska sredstva, procijenjen broj potencijalnih prijavitelja, broj očekivanih projektnih prijedloga i dr.

Osim navedenih, postoje i druga pravila kojima se uređuje funkcioniranje pojedinih segmenata sustava odabira poput rokova za pojedine postupke i uloge pojedinih tijela. Za njihovo predstavljanje nema dovoljno prostora u ovom radu. Međutim, već je iz navedenog opisa sustava odabira projektnih prijedloga razvidno da je riječ o prilično uređenom sustavu s jasno razrađenim pravilima postupanja. Takav pristup trebao bi osigurati visoku razinu standardiziranosti postupanja, što bi u provedbi trebalo rezultirati manjim rizikom od pogrešaka povezanih s mogućim netransparentnim postupanjem u procesu odabira. 
Podaci o provedbi OPKK-a pokazuju da je apsorpcija sredstava EU-a u okviru tog programa prilično slaba. Prema posljednjim dostupnim podacima EK-a, Republika Hrvatska (RH) krajem listopada 2020. iskoristila je oko 35 \% raspoloživih sredstava u okviru OPKK-a. Za usporedbu, prosjek je zemalja članica u vezi sa stopom apsorpcije $51 \% .{ }^{7}$ Nije teško pretpostaviti da je zaostajanje u dinamici iskorištenosti dostupnih sredstava jednim dijelom povezano s načinom funkcioniranja procesa pripreme, prijave, odabira i provedbe projekata, o čemu će biti više riječi u nastavku.

\section{Metodologija i ključni rezultati*}

Predmet vrednovanja sustav je odabira projekata u kontekstu provedbe OPKK-a. Cilj je vrednovanja ocijeniti u kojoj su mjeri postupci vrednovanja bili učinkoviti te u kojoj su mjeri vodili prema odabiru projekata koji najviše doprinose ostvarenju ciljeva iz operativnog programa. Kad je riječ o administrativnoj učinkovitosti, misli se na sposobnost sustava odabira da osigura pravodobni odabir projekata s relativno umjerenim administrativnim naporom za sudionike u procesu. U postupku vrednovanja korištena je kombinacija kvantitativnih i kvalitativnih metoda. Konkretno, riječ je o primjeni triju metoda: (i) analizi dokumentacije poziva za dostavu projektnih prijedloga i podataka o provedbi; (ii) analizi rezultata internetskog upitnika o kvaliteti kriterija za odabir koji su ispunili uspješni prijavitelji, vanjski ocjenjivači i članovi odbora za odabir projekata te (iii) analizi rezultata intervjua s predstavnicima nadležnih državnih tijela za objavu poziva. Konačni zaključci dobiveni su triangulacijom nalaza dobivenih pojedinom istraživačkom metodom.

Analiza dokumentacije obuhvaća pozive za dostavu projektnih prijedloga u okviru OPKK-a objavljene od 2014. godine do 31. 3. 2018. godine. Riječ je o 31 pozivu namijenjenom većem broju prijavitelja (pozivi s natjecateljskim karakterom), čija je pojedinačna vrijednost iznosila najmanje 10 milijuna kuna i u okviru kojih je ugovor o dodjeli bespovratnih sredstava sklopljen s više od jednim korisnikom, a čiji je popis dan u prilogu. ${ }^{8}$ Ukupna

7 Podaci o provedbi OPKK-a dostupni na https://cohesiondata.ec.europa.eu/program mes/2014HR16M1OP001.

* Autori zahvaljuju Ministarstvu regionalnoga razvoja i fondova EU-a na pomoći u pristupu dijelu podataka koji su korišteni za potrebe istraživanja.

${ }^{8}$ Kod pojedinih obrada podataka broj poziva koji je bio predmetom analize manji je od 31 zbog nedostatka podataka. Kompletan popis poziva dan je u prilogu. 
vrijednost tih poziva iznosi 12,38 milijardi kuna, odnosno 399,5 milijuna kuna po jednom pozivu u prosjeku. Internetskim upitnikom prikupljeni su odgovori o postupku odabira projekata od 442 uspješna prijavitelja, 23 vanjska nezavisna ocjenjivača projektnih prijedloga i 22 člana odbora za odabir koji su utvrđivali popise projektnih prijedloga za financiranje. Što se tiče intervjua, oni su provedeni s 35 osoba, predstavnika državnih tijela nadležnih za upravljanje i kontrolu upotrebe sredstava dodijeljenih u okviru OPKK-a (uglavnom različitih ministarstava).

Analiza započinje ocjenom administrativne učinkovitosti postupaka prijave projekata. Korišteni pokazatelji administrativne učinkovitosti postupka prijave prikazani su u Tablici 2.

Tablica 2. Pokazatelji administrativne učinkovitosti postupka prijave projektnib prijedloga na temelju podataka iz natječajne dokumentacije

\begin{tabular}{|c|c|c|c|}
\hline $\begin{array}{l}\text { Redni } \\
\text { broj }\end{array}$ & $\begin{array}{c}\text { Pokazatelji administrativne } \\
\text { učinkovitosti }\end{array}$ & $\begin{array}{c}\text { Izvor } \\
\text { podataka }\end{array}$ & Objašnjenje \\
\hline 1. & $\begin{array}{l}\text { broj obveznih dokumenata } \\
\text { koje prijavitelj treba ispuniti i } \\
\text { dostaviti }\end{array}$ & $\begin{array}{c}\text { natječajna } \\
\text { dokumentacija }\end{array}$ & $\begin{array}{l}\text { manji broj dokumenata } \\
\text { uzima se kao pokazatelj veće } \\
\text { administrativne učinkovitosti }\end{array}$ \\
\hline 2. & $\begin{array}{l}\text { broj učestalo postavljanih } \\
\text { pitanja o natječajnoj } \\
\text { dokumentaciji }\end{array}$ & $\begin{array}{c}\text { natječajna } \\
\text { dokumentacija }\end{array}$ & $\begin{array}{l}\text { manji broj postavljenih } \\
\text { pitanja povezuje se s većom } \\
\text { učinkovitosti, koja se pak } \\
\text { vezuje za veću jasnoću } \\
\text { natječajne dokumentacije }\end{array}$ \\
\hline 3. & $\begin{array}{l}\text { broj izmjena i dopuna } \\
\text { natječajne dokumentacije }\end{array}$ & $\begin{array}{l}\text { obavijesti } \\
\text { o provedbi } \\
\text { natječaja }\end{array}$ & $\begin{array}{l}\text { manji broj izmjena povezuje } \\
\text { se s većom učinkovitosti }\end{array}$ \\
\hline 4. & $\begin{array}{l}\text { broj dana od otvaranja poziva } \\
\text { do donošenja prve odluke o } \\
\text { financiranju }\end{array}$ & $\begin{array}{l}\text { obavijesti } \\
\text { o provedbi } \\
\text { natječaja }\end{array}$ & $\begin{array}{l}\text { kraće trajanje povezuje se } \\
\text { s većom administrativnom } \\
\text { učinkovitosti }\end{array}$ \\
\hline 5. & $\begin{array}{l}\text { veličina podnesene prijave } \\
\text { (broj stranica) }\end{array}$ & anketa & $\begin{array}{l}\text { manji opseg prijave povezuje } \\
\text { se s većom administrativnom } \\
\text { učinkovitosti }\end{array}$ \\
\hline
\end{tabular}

Izvor: Natječajna dokumentacija i obavijesti o provedbi natječaja prikupljeni sa službenih stranica Ministarstva regionalnoga razvoja i fondova EU-a: www.strukturnifondovi.hr i https://efondovi.mrrfeu.hr.

Podaci o broju dokumenata koje prijavitelj mora dostaviti pokazuju da je u glavnini slučajeva riječ o većem broju dokumenata, kao što se može vidjeti na Slici 1. Konkretno, u 59 \% poziva prijavitelji su morali dostaviti najmanje 11 različitih dokumenata, što je priličan broj. U kojoj je mjeri 
natječajna dokumentacija prijaviteljima bila jasna, oslikava broj postavljanih pitanja o samoj dokumentaciji. Prosječan broj učestalo postavljenih pitanja po pozivu iznosi čak 237,5. Podaci na Slici 2. pokazuju da je u više od dvije trećine analiziranih poziva bilo više od 100 postavljenih pitanja. Oba nalaza upućuju na zaključak da u većini slučajeva natječajna dokumentacija nije bila dovoljno jasno napisana, zbog čega su prijavitelji postavljali velik broj pitanja.

Slika 1. Distribucija poziva prema broju dokumenata koje prijavitelj mora dostaviti

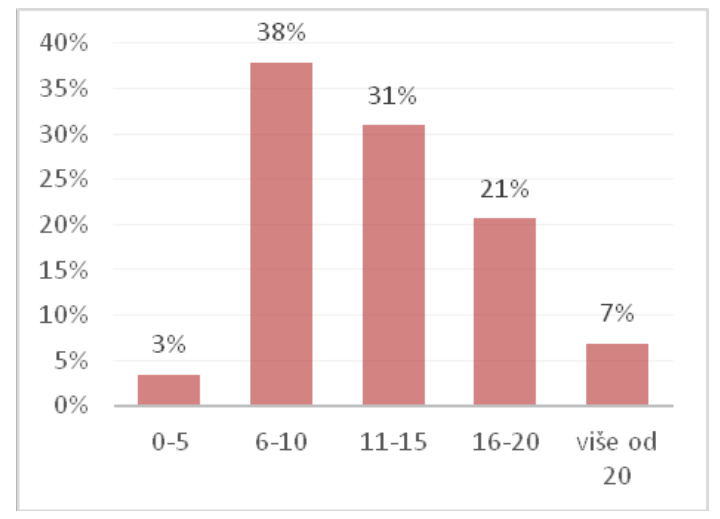

Izvor: Autori, obrada dokumentacije poziva $(\mathrm{n}=29)$.

Slika 2. Distribucija poziva prema broju učestalo postavljenib pitanja o natječajnoj dokumentaciji

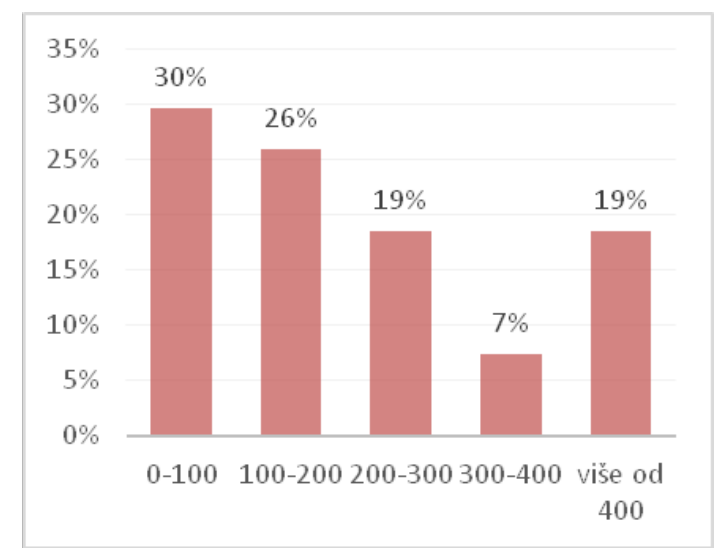

Izvor: Autori, obrada dokumentacije poziva. 
Važan element analize javnih poziva, odnosno procjene njihove kvalitete, jest broj izmjena i dopuna dokumentacije poziva. Izmjene natječajne dokumentacije u pravilu su vodile produljenju rokova za prijavu, što je značilo kasnije ugovaranje odnosno kasniji početak provedbe projekata od prvotno planiranog. Kao što se može vidjeti na Slici 3., u svega 23 \% slučajeva pozivi nisu pretrpjeli nijednu izmjenu, a u čak 47 \% slučajeva bilježe se najmanje dvije ili više izmjena. Takvi rezultati pokazuju da je priprema natječajne dokumentacije kod poziva natjecateljskog karaktera za državnu administraciju bila zahtjevan zadatak koji je u znatnu broju slučajeva imao za posljedicu njezine dopune. Relativno velik broj izmjena i dopuna natječaja zajedno s dugim postupkom odabira doveo je do iznimno dugih rokova za donošenje odluka o odabiru. Prema rezultatima na Slici 4., vidljivo je da je donošenje prve odluke o financiranju trajalo dulje od 120 dana u čak $97 \%$ analiziranih poziva, a najčešće je trajalo od 180 do 360 dana (76 \% svih poziva). Riječ je o iznimno dugim rokovima koji imaju brojne posljedice na apsorpciju i samu kvalitetu provedbe projekta. Jasno je da se u tako dugom razdoblju čekanja na početak provedbe projekta okolnosti od važnosti za uspješnu provedbu projekta mogu znatno izmijeniti.

Za usporedbu, prema rezultatima istraživanja o postupcima odabira projekata koje je proveo Rambùll (2012), između 31 i 49 \% ispitanika korisnika fondova EU-a u Njemačkoj, Sloveniji, Austriji, Češkoj, Nizozemskoj i Slovačkoj, rezultate ocjenjivanja čekalo je kraće od tri mjeseca. Iz navedenog je vidljivo da u Hrvatskoj procedure odabira projekata traju znatno dulje nego u drugim zemljama članicama EU-a.

Slika 3. Broj izmjena i dopuna poziva

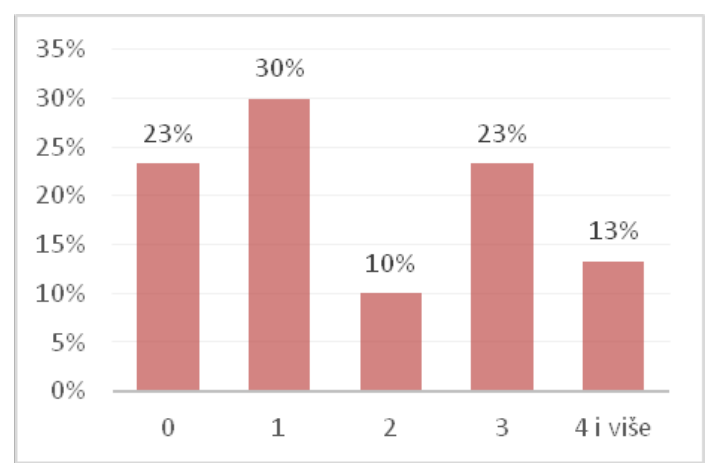

Izvor: Autori, obrada dokumentacije poziva $(\mathrm{n}=31)$. 
Slika 4. Broj dana od otvaranja poziva do donošenja prve odluke o financiranju

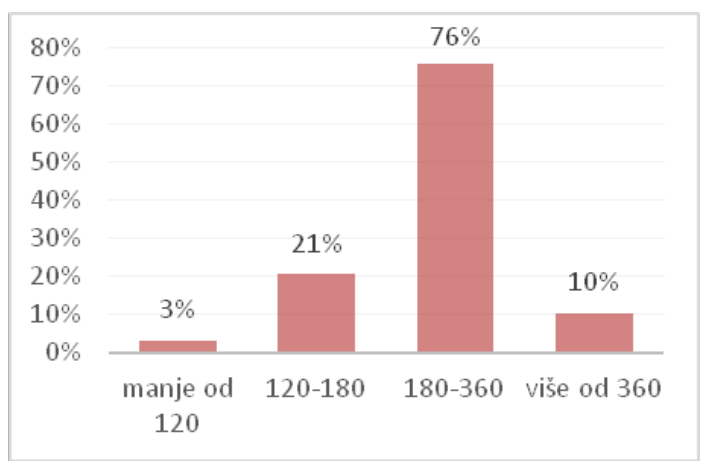

Izvor: Autori, obrada dokumentacije poziva $(\mathrm{n}=31)$.

Slika 5. Distribucija poziva prema veličini prijave uključujući sve priloge (ukupan broj stranica)

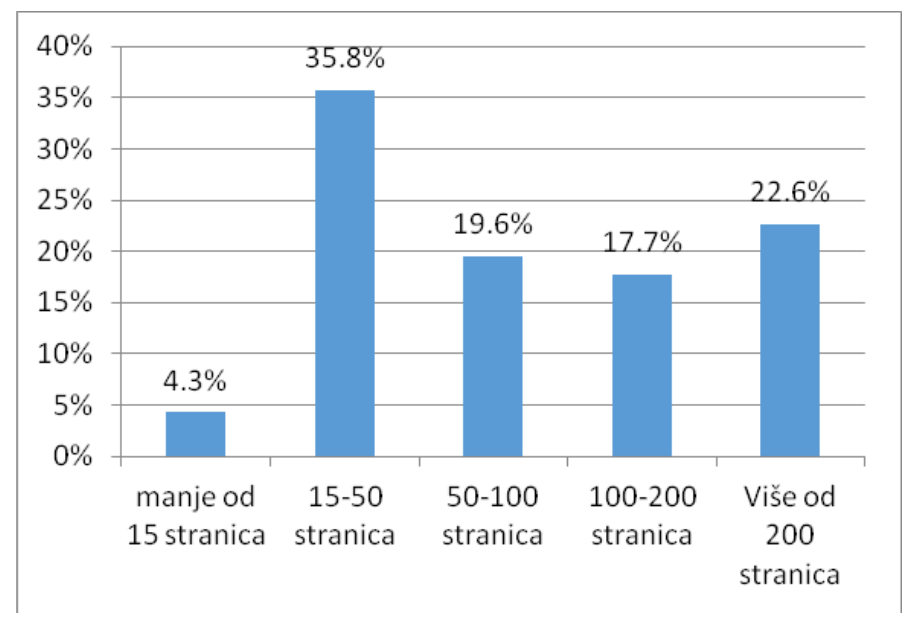

Izvor: Autori prema rezultatima ankete prijavitelja $(\mathrm{n}=327)$.

Prema rezultatima na Slici 5., iskustva prijavitelja koja se odnose na veličinu podnesene prijave prilično su podijeljena. Tako je 39,3 \% prijavitelja izjavilo da je cijela prijava s prilozima imala više od 100 stranica, što upućuje na to da je kod njih bila riječ o zahtjevnim javnim pozivima. $S$ druge strane, $41 \%$ ispitanika naveo je da im je prijava imala manje od 50 stranica, iz čega se može zaključiti da je bila riječ o manje zahtjevnim pozivima. Analiza na razini pojedinih javnih poziva pokazuje da se prema veličini 
prijava javni pozivi vezani za energetsku obnovu zgrada, obnovu kulturne baštine, promicanje održivog razvoja prirodne baštine te za modernizaciju i izgradnju studentskih domova mogu izdvojiti kao pozivi s vrlo opsežnim prijavama projekata. Primjeri su poziva s relativno kratkim prijavama projekta: „Poboljšanje poslovnog razvoja i tehnološke spremnosti MSP-ova E-impuls“, „Internacionalizacija poslovanja MSP-ova“ i „Certifikacijom proizvoda do tržišta“.

Međutim, primjer spomenutog poziva „Poboljšanje poslovnog razvoja i tehnološke spremnosti MSP-ova E-impuls“ pokazuje da kratka prijava projekta ne mora nužno značiti i veću administrativnu učinkovitost u provedbi natječaja. Kod tog je poziva prošlo čak 370 dana od otvaranja poziva do donošenja prve odluke o financiranju, što je znatno dulje od većine natječaja u području malog i srednjeg poduzetništva.

U sklopu istraživanja predstavnici tijela državne uprave uključeni u sustav upravljanja i kontrole OPKK-a 2014. - 2020. ispitivani su o administrativnom teretu tijekom pripreme natječaja i provedbe programa, a nalazi su prikazani na Slici 6.

Slika 6. Administrativni teret pripreme natječaja i provedbe programa državnim službenicima

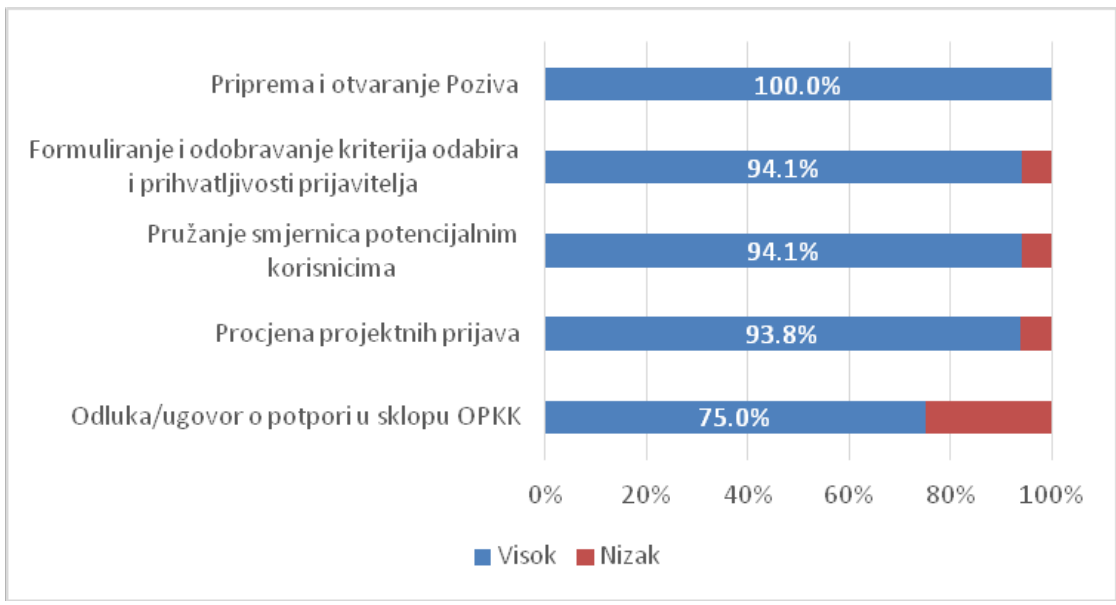

Izvor: Autori prema rezultatima ankete $(\mathrm{n}=35)$.

Slika 6. pokazuje da je administrativni teret koji snose državni službenici u pripremi natječaja i provedbe programa procijenjen kao visok. Najveće opterećenje zahtijeva faza pripreme i provedbe natječaja, ali opterećenje 
je visoko i tijekom svih ostalih faza odabira projekata. Tek kod pripreme odluke i ugovora o dodjeli potpore nešto manji udio ispitanika smatra da je riječ o visokome administrativnom opterećenju zahtjeva (75\%).

Osim toga, sugovornici smatraju da postoje nepotrebna kašnjenja u postupku odabira kao i da je postupanje u elektroničkom sustavu za podnošenje prijava, eFondovi, previše kompleksno te ga je potrebno unaprijediti. U sam je proces uključeno previše institucija, dok su državni i javni službenici istodobno preopterećeni velikim brojem obrazaca i dopisa koje je potrebno pripremiti za svaki projektni prijedlog. Također, premalen broj osoba angažiranih na pripremi poziva i vrednovanja projektnih prijedloga povećava administrativni teret službenicima, što ugrožava kvalitetu realiziranog posla. Ukupno gledano, čini se da je za znatan dio prijavitelja dosadašnji pristup izradi tražene dokumentacije za prijavu projekta bio (pre)zahtjevan.

Kad je riječ o ocjeni kvalitete primijenjenih kriterija, postoji jedan temeljni problem koji se odnosi na pristup mjerenju kvalitete kriterija odabira. Naime, u postojećem sustavu planiranja ne utvrđuju se ciljane (planirane) vrijednosti pokazatelja koje se žele ostvariti provedbom određenog poziva, odnosno u planiranju poziva nadležna državna tijela ne utvrđuju kvantitativne ishode koje planiraju ostvariti njegovom provedbom. To znači da ne postoji osnovna referentna vrijednost s pomoću koje bi se moglo zaključiti u kojoj je mjeri postupak odabira projekata osigurao dostizanje prethodno utvrđenih ciljanih vrijednosti. $U$ takvim okolnostima mjerenje kvalitete postupaka odabira provedeno je alternativnim načinima, prije svega analizom stavova ključnih dionika uključenih u proces pripreme i provedbe poziva za dostavu projektnih prijedloga. Ispitanici su ocjenjivali različite aspekte kvalitete kriterija odabira ocjenama u rasponu od jedan (najslabija moguća ocjena) do pet (najbolja moguća ocjena).

Većina ispitanika daje prilično visoke ocjene kvalitete sustava odabira. Tako je, primjerice, prosječna ocjena sposobnosti sustava odabira da usmjerava na projekte koji donose najveću dodanu vrijednost iznosila 3,77 (Slika 7.). Ista ocjena dodijeljena je za sposobnost prepoznavanja (dobrog) dizajna i zrelosti projekta. Vrlo slične ocjene, iako nešto niže, uspješni prijavitelji dodijelili su za prepoznavanje financijske održivosti projekta kao i provedbenih kapaciteta. 
Slika 7. Ocjena kvalitete sustava odabira projekata od korisnika

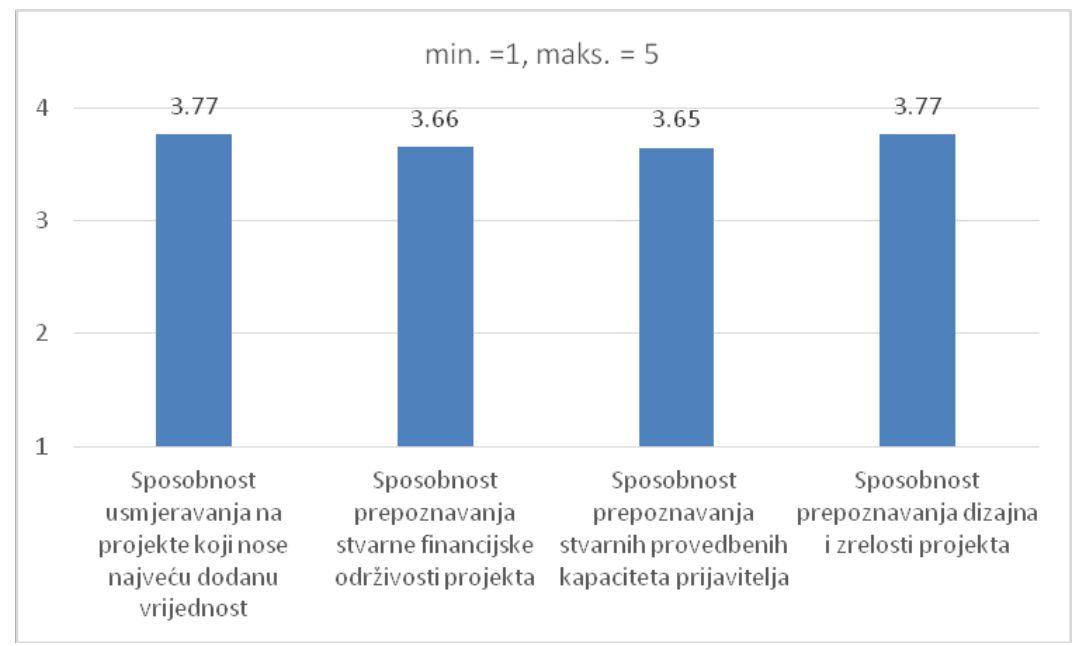

Izvor: Autori prema rezultatima ankete $(\mathrm{n}=327)$.

Slično kao i sami korisnici sredstava, članovi odbora za odabir i vanjski ocjenjivači dali su relativno visoke prosječne ocjene kvaliteti kriterija odabira na tragu onih koje su dali i uspješni prijavitelji. Na pitanje u kojoj su mjeri primijenjeni kriteriji usmjeravali na odabir onih projekata koji najviše doprinose relevantnomu specifičnom cilju iz OPKK-a, članovi odbora za odabir na ljestvici od jedan do pet, dali su prosječnu ocjenu 4,1, a vanjski ocjenjivači 4,0 , što je veća ocjena od one koju su dali korisnici. Članovi odbora za odabir i vanjski ocjenjivači najslabiju su ocjenu dodijelili kvaliteti potkriterija odnosno razradi dodatnih pitanja za ocjenu kriterija. Tako je prosječna ocjena koju su dodijelili članovi odbora za odabir bila 3,85 , a ona koju su dodijelila vanjski ocjenjivači 3,5 .

Predstavnici ključnih tijela za provedbu OPKK-a (koji nisu bili u funkciji članova odbora za odabir) u intervjuima su više puta istaknuli ZNP-ove kao čvrst okvir koji osigurava da se ocjenjuje na cjelovit način. Svi sugovornici također navode da kriteriji odabira uglavnom doprinose ciljevima relevantnih strategija i planova na nacionalnoj razini. Međutim, to nikako ne znači da ne postoje konkretne mogućnosti za poboljšanje sustava. Slika 8. prikazuje stavove ispitanika o nedostacima kriterija odabira. Većina korisnika smatra da nije bilo znatnih nedostataka (63,7 \%). Ipak, manji dio smatra da su raspodjela bodova po pojedinim pitanjima, formulacija pitanja te raspodjela težinskih udjela među kriterijima za ocjenjivanje bile loše. Najkritičniji su stavovi ocjenjivača. Svega 39 \% ocjenjivača smatra da 
kriteriji odabira nemaju nedostataka, što se može ocijeniti jasnim pokazateljem potrebe za njihovim unaprjeđenjem. Najveće nedostatke ocjenjivači vide u lošoj raspodjeli težinskih udjela među kriterijima za ocjenjivanje $(33,3 \%)$ te u lošoj formulaciji pitanja korištenih za ocjenu pojedinih kriterija (22,2 \%). Članovi odbora za odabir imaju nešto pozitivnije viđenje kvalitete sustava, koje je na tragu stavova korisnika. Najveći problem članovi odbora za odabir vide u formuliranju pitanja korištenih za ocjenu pojedinih kriterija (30 \% ispitanika), dok manji dio članova prepoznaje probleme u ostalim dimenzijama ocjene kvalitete.

Slika 8. Stav pojedinib ispitanika o ključnim nedostacima kriterija odabira

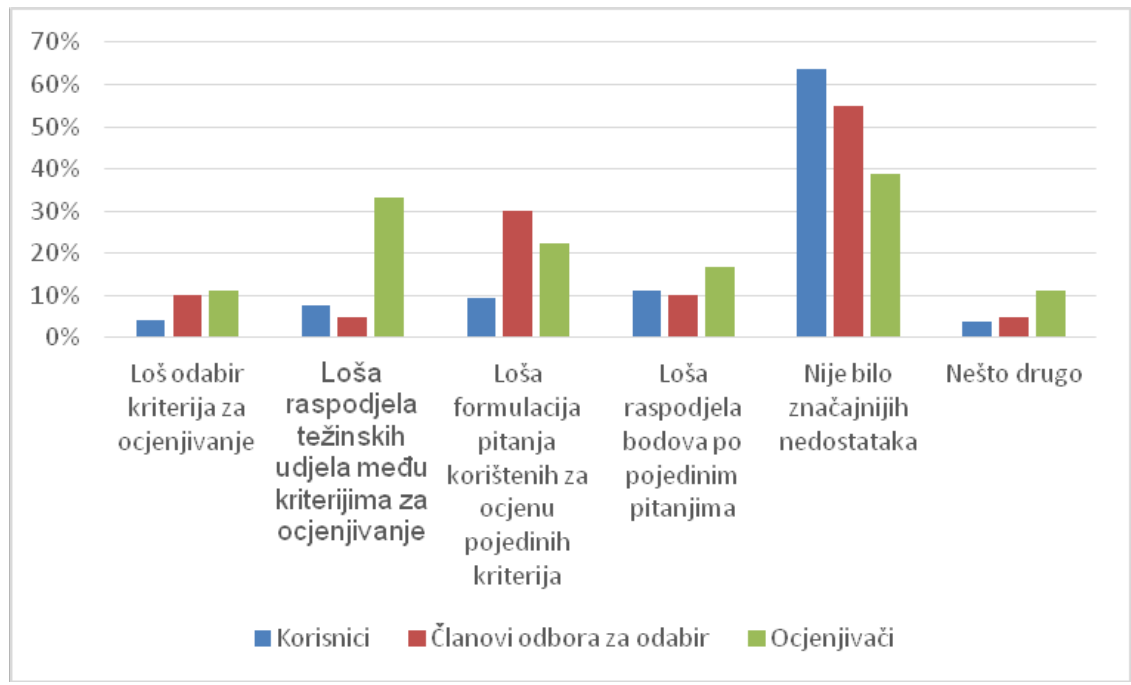

Izvor: Autori prema rezultatima ankete ( $\mathrm{n}=260$ za korisnike, $\mathrm{n}=20$ za članove odbora za odabir i $n=18$ za ocjenjivače).

*Napomena: maksimalan je broj odgovora dva, stoga zbroj udjela ne odgovara vrijednosti $100 \%$.

Još jedan važan pokazatelj kvalitete sustava odabira projekata jest stupanj informiranosti prijavitelja o rezultatima vrednovanja projektnog prijedloga. Prema odgovorima ispitanika, 63,9\% korisnika smatra da su dodijeljeni bodovi bili potpuno ili uglavnom dobro obrazloženi prema pojedinim kriterijima ocjenjivanja. Posebno zabrinjava što 12,3 \% uspješnih prijavitelja tvrdi da uopće nije dobilo povratnu informaciju o dodijeljenim bodovima. Nadalje, dodatnih 12,3\% uspješnih prijavitelja tvrdi da je dobilo povratne informacije o bodovanju svojeg prijedloga, ali bez obrazloženja, 
odnosno argumentacije za takve ocjene. Takvi rezultati potvrđuju prethodne nalaze iz kojih proizlazi da ima još dosta prostora za poboljšanja postojećeg sustava odabira projekata.

U potrazi za dodatnim pojašnjenjem uzroka koji doprinose nedostacima sadašnjeg sustava, ispitanici su u intervjuima istaknuli da je važna zapreka prevelika fluktuacija zaposlenika u tijelima nadležnim za upravljanje OPKK-om, što za posljedicu ima znatno usporavanje postupaka odabira. Također, ispitanici smatraju da je broj službenika koji rade na poslovima vrednovanja prijava još premalen te ga je potrebno povećati. Ujedno, smatraju da je nužno osnažiti stručne kompetencije ocjenjivača u državnim tijelima. Problem nedostatka kapaciteta vidljiv je i u sustavu za elektroničku prijavu projekata eFondovi. Iako je taj sustav korisnicima donio velike prednosti i olakšanja u procesu prijave projekta, ispitanici iz državnih tijela smatraju da nije pogodan za proces odabira. Naime, zbog prevelika udjela ručnog unosa, odnosno nedovoljne povezanosti i automatizacije pojedinih procesa, sustav produljuje postupak odabira.

Dodatni važni nedostaci sustava odabira utvrđeni su pregledom ZNPova i natječajne dokumentacije objavljenih poziva za dostavu projektnih prijedloga. Jedan od važnijih problema jest da sami ZNP-ovi nisu jasno utvrdili koji se kriterij odabira odnosi isključivo na mjerenje doprinosa projekta ciljevima poziva odnosno OPKK-a. Zbog toga u praksi često dolazi do nekonzistentne primjene kriterija „Vrijednost za novac" koji se u pojedinim pozivima razrađuje tako da mjeri troškovnu učinkovitost projekta (očekivano s obzirom na način definiranja kriterija), a u dijelu poziva razrađuje se kao mjerilo potencijalnog doprinosa projekta ispunjenju ciljeva poziva. Nadalje, u brojnim je slučajevima uočen prilično nizak bodovni udjel kriterija kojima se ocjenjuje doprinos projekta ciljevima poziva (a koji bi trebali biti ključni u ukupnoj ocjeni) u odnosu na neke druge aspekte ocjenjivanja. Konačno, treba istaknuti da se čini da ocjenjivanje projektnih prijedloga ima tendenciju postati maksimalno objektivizirano upotrebom kvantitativnih pokazatelja, ne ostavljajući pritom ocjenjivaču mogućnost da iznese svoje osobno mišljenje o pojedinom aspektu projektnog prijedloga. Na taj se način znatno umanjuju koristi koje donosi oslanjanje na iskustvo ocjenjivača i njegovo dubinsko poznavanje materije kao i njegova sposobnost da uoči rizike u provedbi, bez obzira na ono što je napisano u samoj prijavi. 


\section{Zaključci}

Provedeno istraživanje bavi se problemom kvalitete upravljanja kohezijskom politikom u Hrvatskoj fokusiranjem na vrlo važan segment upravljanja, a to je funkcioniranje sustava odabira projekata u okviru OPKK-a. Analiza sustava odabira pokazuje kako su nadležna državna tijela stvorila prilično standardiziran sustav odabira projekata s brojnim pravilima koja bi trebala osigurati što veću transparentnost te smanjiti eventualne proceduralne greške u postupanju. Po tome se Hrvatska može svrstati u skupinu novih zemalja članica poput Slovenije, Češke, Slovačke i drugih kojima je, prema Rambùll (2012), zajedničko obilježje zahtjevna natječajna dokumentacija te kompleksna metodologija ocjenjivanja projektnih prijedloga koja se uglavnom zasniva na kvantitativnom bodovanju i uključenosti vanjskih ocjenjivača. Međutim, daljnja analiza pokazuje da je istodobno sustav odabira projekata u Hrvatskoj prilično neučinkovit. Neučinkovitost proizlazi iz nekoliko razloga. Prije svega, opseg dokumentacije koji se traži od prijavitelja prilično je velik kod glavnine natječaja, što je opet povezano s veličinom prijava koja je kod pojedinih javnih poziva znatna. Zatim, sama natječajna dokumentacija očito je prilično nejasna prijaviteljima, s obzirom na vrlo velik broj učestalo postavljanih pitanja. Upravo su takve nejasnoće i jedan od čimbenika koji dovode do izmjena i dopuna natječajne dokumentacije. Međutim, vrijeme obrade prijava ono je što najviše utječe na nisku učinkovitost sustava. Ono je znatno dulje od vremena koje propisuju ZNP-ovi kao i od vremena koje je navedeno u prethodnim studijama o provedbi selekcijskih postupaka u drugim zemljama EU-a.

Uočene su znatne razlike u učinkovitosti provedbe pojedinih postupaka odabira. To se jednim dijelom može povezati s razlikama u složenosti područja koje je predmet financiranja. Primjerice, može se očekivati da će natječaj kojim se financiraju veliki projekti u području istraživanja i razvoja biti složeniji nego natječaji kojima se financiraju troškovi pribavljanja certifikata za proizvodnju ili kojima se financira projektna dokumentacija. Međutim, katkad su razlike više povezane s planiranjem uvjeta samog natječaja koji utječu na čimbenike poput odaziva prijavitelja ili pak s administrativnim kapacitetima nadležnih državnih tijela.

Kada je u pitanju usmjerenost kriterija odabira na projekte koji najviše doprinose ostvarenju ciljeva OPKK-a, čini se da sustav u tom dijelu relativno dobro funkcionira. Međutim, valja spomenuti i nekoliko važnih nedostataka. Kriteriji su uglavnom dobro razrađeni i pokrivaju većinu ključnih dimenzija relevantnih za odlučivanje o odabiru. Određeni nedostaci postoje 
$\mathrm{u}$ formuliranju kriterija za ocjenu doprinosa projektnog prijedloga $\mathrm{u}$ ispunjenju ciljeva poziva, zatim u formuliranju potpitanja korištenih za ocjenu pojedinih kriterija te u raspodjeli težinskih udjela među kriterijima. Jedan je od važnijih nedostataka pitanja za ocjenu kvalitete projektnih prijedloga i način njihova definiranja koji ne dopušta bitno ocjenjivanje temeljeno na znanju i iskustvu ocjenjivača.

(Pre)velika razrađenost sustava odabira dovela je do znatna administrativnog opterećenja sudionika u postupku odabira. Stoga se može zaključiti da je sustav odabira projekata EU-a primjer procesa pozlaćivanja u kojem nacionalna tijela na prilično neučinkovit način osiguravaju poštivanje odgovarajućih odredbi iz zakonodavstva EU-a. Takav pristup u kombinaciji s manjkom stručnih kapaciteta za ocjenjivanje projektnih prijedloga, poglavito kad su u pitanju složeniji projekti, nužno vodi sporijem ugovaranju dostupnih sredstava, odnosno slabijem povlačenju raspoloživih sredstava iz europskog proračuna. Druga negativna posljedica moguće je odustajanje dijela potencijalnih prijavitelja od same prijave jer im je preskupo ulagati vlastite resurse u tako neučinkovit proces odabira projekata. Stoga je od presudne važnosti kontinuiran rad nadležnih državnih tijela na smanjenju administrativne složenosti sustava te jačanju ljudskih kapaciteta u dijelu koji se odnosi na odabir projekata. Intenzivan i stalan dijalog o nedostacima sadašnjeg sustava i mogućnostima za njegovo poboljšanje između korisnika, vanjskih ocjenjivača i tijela nadležnih za upravljanje fondovima EU-a važan je, ako ne i ključan korak. Također, veću pozornost trebalo bi usmjeriti na smanjenje opsega tražene dokumentacije kod dijela natječaja, odnosno na preuzimanje dobre prakse natječaja koji su se već pokazali vrlo učinkovitima.

\section{Literatura}

Bachtler, J., \& Taylor, S. (1999). Objective 2: Experiences, lessons and policy implications. Glasgow: European Policies Research Centre, University of Strathclyde.

Bachtler, J., Mendez, C., \& Oraže, H. (2014). From conditionality to europeanization in Central and Eastern Europe: Administrative performance and capacity in cohesion policy. European Planning Studies, 22(4), 735-757, https:// doi.org/10.1080/09654313.2013.772744.

Batterbury, S. C. E. (2006). Principles and purposes of European Union Cohesion policy evaluation, Regional Studies, 40, 179-188, https://doi. org/10.1080/00343400600600504.

Dabrowski, M. (2012). Shallow or deep Europeanisation? The uneven impact of EU cohesion policy on the regional and local authorities in Poland, Envi- 
ronment and Planning C: Government and Policy, 30(4), 730-745, https://doi. org/10.1068/c1164r.

Dutra, C., Ribeiro, J., \& de Carvalho, M. (2014). An economic-probabilistic model for project selection and prioritization. International Journal of Project Management, 32(6), 1042-1055, https://doi.org/10.1016/j.ijproman.2013.12.004.

Đulabić, V. (2017). Lokalna i regionalna samouprava i korištenje sredstava iz fondova Europske unije. U: M. Biban \& I. Vukušić (Ur.), Zbornik radova Pametna lokalna samouprava (1st ed.) (str. 25-37). Novalja - Split - Zagreb, Hrvatska: Grad Novalja.

Ecorys, \& IRMO (2019). Usluga vrednovanja za Ministarstvo regionalnoga razvoja i fondova EU u ulozi upravljačkog tijela operativnog programa „Konkurentnost i kohezija 2014. - 2020." te koordinacijskog tijela ESI fondova u Republici Hrvatskoj. Ministarstvo regionalnoga razvoja i fondova EU-a.

European Commission (2013). EVALSED: The resource for the evaluation of socio-economic development. Evaluation guide. Dostupno na https://ec.europa. eu/regional_policy/en/information/publications/evaluations-guidance-documents/2013/evalsed-the-resource-for-the-evaluation-of-socio-economic-development-evaluation-guide.

European Commission (2016). 4th Meeting of the high level expert group on monitoring simplification for beneficiaries of ESI funds. Dostupno na https:// ec.europa.eu/futurium/en/system/files/ged/hlg_16_0008_00_conclusions_ and_recomendations_on_goldplating_final.pdf.

European Commission (2018). Simplification handbook - 80 simplification measures in cohesion policy 2014 - 2020. Dostupno na https://ec.europa.eu/regional_ policy/en/information/publications/factsheets/2018/simplification-handbook80-simplification-measures-in-cohesion-policy-2021-2027.

European Court of Auditors (2018). Selection and monitoring for ERDF and ESF projects in the 2014-2020 period are still mainly output-oriented. Special Report 21/2018.

Europski parlament, \& Vijeće (2013). Uredba (EU) br. 1303/2013 Europskog parlamenta i Vijeća od 17. prosinca 2013. o utvrđivanju zajedničkih odredbi o Europskom fondu za regionalni razvoj, Europskom socijalnom fondu, Kohezijskom fondu, Europskom poljoprivrednom fondu za ruralni razvoj i Europskom fondu za pomorstvo i ribarstvo i o utvrđivanju općih odredbi o Europskom fondu za regionalni razvoj, Europskom socijalnom fondu, Kohezijskom fondu i Europskom fondu za pomorstvo i ribarstvo te o stavljanju izvan snage Uredbe Vijeća (EZ) br. 1083/2006.

Ferry, M., Gross, F., Bachtler, J., \& McMaster, I. (2007). Turning strategies into projects: The implementation of 2007-2013 Structural Funds programmes. IQ-Net Thematic Paper, 20(2), 1-132. Glasgow, Scotland: European Policies Research Centre.

Florio, M., Morretta, V., \& Willak, W. (2018). Cost-benefit analysis and European Union cohesion policy: Economic versus financial returns in investment project appraisal. Journal of Benefit-Cost Analysis, 9(1), 147-180, https://doi. org/10.1017/bca.2018.4. 
Idczak, P., \& Musiałkowska, I. (2014). Assessment of the system of project selection under the cohesion policy. The case of the Wielkopolska Region. Evaluačni teorie a praxe, 2(2), 1-31.

Jigeesh, N. (2012). Selection of project as important beginning for information technology project management. The IUP Journal of Operations Management, 11(1), 42-49.

Maleković, S., Tišma, S., Jelinčić, D., \& Boromisa, A.-M. (2019). Can evaluation trigger change? The case of the interim evaluation of the Croatian tourism development strategy. International Review of Economics and Business, 22(2), 55-72, https://doi.org/10.2478/zireb-2019-0027.

Manzella, G. P., \& Mendez, C. (2009). The turning points of EU cohesion policy. Working Paper Report to Barca Report. Dostupno na https://strathprints. strath.ac.uk/38743/.

Meredith, J., \& Mantel, S. (2009). Project management. A managerial approach (7th Ed.). Hoboken, SAD: John Wiley \& Sons, Inc.

MRRFEU (2018). Zajednička nacionalna pravila (br. 06) o postupcima odabira projekata i odobrenja potpora. Dostupno na https://strukturnifondovi.hr/zajednicka-nacionalna-pravila/.

MRRFEU. Operativni program Konkurentnost i kohezija 2014. - 2020. Dostupno na https://strukturnifondovi.hr/eu-fondovi/esi-fondovi-2014-2020/opkonkurentnost-i-kohezija/.

Polverari, L. (2011). The effectiveness of cohesion policy implementation: Conflicting accountabilities and accountability efficiency trade offs. Paper presented at the conference What Future for Cohesion Policy? An academic and policy debate. Bled, Slovenia.

Puljiz, J., Maleković, S., \& Keser, I. (2018). Cohesion policy in Croatia: what have we accomplished so far? In Z. Petak \& K. Kotarski (Eds.), Policy-making at the European Periphery: The case of Croatia (pp. 285-302). London, UK: Palgrave Macmillan, https://doi.org/10.1007/978-3-319-73582-5_15.

Rambùll (2012). Comparative study of the project selection process Applied in Cobesion Policy Programmes 200 - 2013 in a number of member states. European Commission, Directorate General for Regional Policy.

Sutcliffe, J. B. (2000). The 1999 reform of the structural fund regulations: Multilevel governance or renationalization? Journal of European Public Policy, 7(2), 290-309, https://doi.org/10.1080/135017600343205.

Tsipouri, L. J. (2014). Smart governance of the internal market for business. Brussels, Belgium: European Economic and Social Committee.

Van den Broucke, S., Dargent, G., \& Pletschette, M. (2011). Development and assessment of criteria to select projects for funding in the EU health programme. European Journal of Public Health, 22(4), 598-601, https://doi. org/10.1093/eurpub/ckr066.

Wostner, P. (2008). Micro-efficiency of the EU Cohesion Policy. Retrieved from https://ssrn.com/abstract=1083477, https://doi.org/10.2139/ssrn.1083477. 


\section{Internet izvori}

Europski strukturni i investicijski fondovi, https://cohesiondata.ec.europa.eu/ programmes/2014HR16M1OP001

Ministarstvo regionalnoga razvoja i fondova EU-a, https://efondovi.mrrfeu.hr; www.strukturnifondovi.hr

\section{Prilog: Popis javnih poziva uključenib u analizu}

\begin{tabular}{|c|c|c|}
\hline $\begin{array}{l}\text { Redni } \\
\text { broj }\end{array}$ & Poziv & $\begin{array}{l}\text { Iznos bespovrat- } \\
\text { nih sredstava u } \\
\text { kunama }\end{array}$ \\
\hline 1. & Vrhunska istraživanja znanstvenih centara izvrsnosti & 380.000 .000 \\
\hline 2. & $\begin{array}{l}\text { Ulaganje u organizacijsku reformu i infrastrukturu u sekto- } \\
\text { ru istraživanja, razvoja i inovacija }\end{array}$ & 760.000 .000 \\
\hline 3. & $\begin{array}{l}\text { Promicanje održivog korištenja prirodne baštine u nacio- } \\
\text { nalnim parkovima i parkovima prirode }\end{array}$ & 651.576 .579 \\
\hline 4. & $\begin{array}{l}\text { Ograničeni poziv na dostavu projektnih prijedloga za do- } \\
\text { djelu bespovratnih sredstava za podršku razvoju Centara } \\
\text { kompetencija }\end{array}$ & 785.977 .500 \\
\hline 5. & $\begin{array}{l}\text { Povećanje razvoja novih proizvoda i usluga koji proizlaze iz } \\
\text { aktivnosti istraživanja i razvoja }\end{array}$ & 998.000 .000 \\
\hline 6. & Razvoj poslovne infrastrukture & 640.000 .000 \\
\hline 7. & Kompetentnost i razvoj MSP-ova & 1.342 .000 .000 \\
\hline 8. & Komercijalizacija inovacija u poduzetništvu & 114.000 .000 \\
\hline 9. & $\begin{array}{l}\text { Pružanje visokokvalitetnih usluga za MSP-ove putem po- } \\
\text { duzetničkih potpornih institucija (PPI) }\end{array}$ & 22.800 .000 \\
\hline 10. & $\begin{array}{l}\text { Podrška razvoju MSP-ova u turizmu povećanjem kvalitete } \\
\text { i dodatne ponude hotela }\end{array}$ & 304.000 .000 \\
\hline 11. & Ulaganje u znanost i inovacije - prvi poziv & 158.460 .000 \\
\hline 12. & Razvoj infrastrukture poduzetničkih zona & 76.000 .000 \\
\hline 13. & Internacionalizacija poslovanja MSP-ova & 38.000 .000 \\
\hline 14. & Certifikacijom proizvoda do tržišta & 38.000 .000 \\
\hline 15. & Inovacije novoosnovanih MSP-ova & 74.000 .000 \\
\hline 16. & $\begin{array}{l}\text { Povećanje energetske učinkovitosti i korištenja obnovljivih } \\
\text { izvora energije u proizvodnim industrijama }\end{array}$ & 114.000 .000 \\
\hline 17. & $\begin{array}{l}\text { Internacionalizacija poslovanja MSP-ova putem organiza- } \\
\text { cija za poslovnu podršku }\end{array}$ & 38.000 .000 \\
\hline
\end{tabular}




\begin{tabular}{|c|c|c|}
\hline 18. & $\begin{array}{l}\text { Unaprjeđivanje infrastrukture centara za socijalnu skrb } \\
\text { kao podrška procesu deinstitucionalizacije - faza } 1\end{array}$ & 73.125 .000 \\
\hline 19. & $\begin{array}{l}\text { Izgradnja proizvodnih kapaciteta MSP-ova i ulaganje u } \\
\text { opremu }\end{array}$ & 760.000 .000 \\
\hline 20. & Ulaganje u proizvodnu tehnologiju MSP-ova & 357.200 .000 \\
\hline 21. & $\begin{array}{l}\text { Energetska obnova zgrada i korištenje obnovljivih izvora } \\
\text { energije u javnim ustanovama koje obavljaju djelatnost od- } \\
\text { goja i obrazovanja }\end{array}$ & 348.785 .283 \\
\hline 22. & Energetska obnova višestambenih zgrada & 565.520 .410 \\
\hline 23. & Građenje reciklažnih dvorišta & 214.500 .000 \\
\hline 24. & Sanacija i zatvaranje odlagališta neopasnog otpada & 80.000 .000 \\
\hline 25. & $\begin{array}{l}\text { Provedba programa izobrazno-informativnih aktivnosti o } \\
\text { održivom gospodarenju otpadom }\end{array}$ & 47.200 .000 \\
\hline 26. & $\begin{array}{l}\text { Poboljšanje konkurentnosti i učinkovitosti MSP-ova u po- } \\
\text { dručjima s razvojnim posebnostima kroz informacijske i } \\
\text { komunikacijske tehnologije (IKT) }\end{array}$ & 110.000 .000 \\
\hline 27. & $\begin{array}{l}\text { Energetska obnova i korištenje obnovljivih izvora energije } \\
\text { u zgradama javnog sektora }\end{array}$ & 380.000 .000 \\
\hline 28. & Promicanje održivog razvoja prirodne baštine & 400.000 .000 \\
\hline 29. & $\begin{array}{l}\text { Priprema i provedba integriranih razvojnih programa te- } \\
\text { meljenih na obnovi kulturne baštine }\end{array}$ & 903.005 .800 \\
\hline 30. & $\begin{array}{l}\text { Poboljšanje poslovnog razvoja i tehnološke spremnosti } \\
\text { MSP-ova E-impuls }\end{array}$ & 250.000 .000 \\
\hline 31. & $\begin{array}{l}\text { Poboljšanje isplativosti i pristupa dnevnim bolnicama i/ili } \\
\text { dnevnim kirurgijama }\end{array}$ & 1.359 .047 .566 \\
\hline
\end{tabular}

Izvor: www.strukturnifondovi.hr. 


\title{
EFFICIENCY OF THE CROATIAN PUBLIC ADMINISTRATION IN THE SELECTION OF PROJECTS CO-FINANCED BY THE EUROPEAN UNION FUNDS
}

\begin{abstract}
Summary
In order to improve the management of cohesion policy funds of the European Union (EU) in Croatia, an obligation bas been introduced to carry out an independent evaluation procedure for the preparation and implementation of planning documents of this policy. The intention is to monitor its implementation and improve its quality, thus ensuring the greatest possible positive effects of investments in each member state and the EU as a whole. The research focused on the quality of implementation of cohesion policy in Croatia by choosing a very important segment of the management process - the evaluation of the project selection system within the Operational Programme Competitiveness and Cohesion 2014-2020 as the financially most important EU programme in Croatia. The development and application of project selection criteria falls within the competence of each EU member state, but with the obligation to respect the key principles set out in the EU legislation. The analysis of the selection system bas shown that the national authorities have created a fairly standardised project selection system with a number of rules that should ensure a bigh level of transparency and reduce any procedural errors of conduct. In that respect, Croatia can be placed among the new member states characterised by demanding tender documentation and a complex methodology for evaluating project proposals. Further analysis has shown that the project selection system is quite lengthy and inefficient. The administrative complexity is burdensome for all participants in the project selection process, thus making the project selection system a typical example of gold-plating in which national authorities ensure that the relevant provisions of EU law are respected in a fairly inefficient way. In such circumstances, the overall positive effects of the selection system related to transparency and reduction of procedural errors are diminished.

Keywords: cohesion policy, Croatia, efficiency of public administration, evaluation, project selection
\end{abstract}

